\title{
Origin oriented management of inverted papilloma of the
} frontal sinus*

\author{
Reda H. Kamel, Ahmed F. Abdel Fattah, Ayman G. Awad \\ Department of Otorhinolaryngology, Cairo University, Cairo, Egypt
}

Rhinology 50: 262-268, 2012

DOI:10.4193/Rhino11.259

*Received for publication:

December 17, 2011

Accepted: March 7, 2012

\section{Summary}

Background: Despite the great progress in endoscopic management of inverted papilloma (IP), involvement of the frontal sinus (FS) remains a challenge.

Methodology: Six cases of FS IP were assessed. Extent of surgery included simple frontal recess clearance, extended frontal sinusotomy, and modified Lothrop approach. There was no need for adjuvant frontal trephination or an external osteoplastic flap.

Results: FS involvement was observed in 6 out of 119 cases of IP (5\%). In one case, IP was originating from the FS and in four it was extending to the FS. The sixth case had a wide origin from the anterior ethmoid and FS. Complete resection of FS IP was achieved in all cases with a single incidence of CSF leak. No recurrence was identified after a follow-up period of an average of 27 months.

Conclusions: FS IP originating outside FS can be delivered transnasally with or without frontal ostium widening and preserving FS mucosa and bone. Inverted papillomata originating from FS proper and those with origin from inside and outside the FS can also be resected tranasnasally after widening of the frontal ostium with removal of surrounding mucosa and drilling or curettage of underlying bone at attachment sites.

Key words: inverted papilloma, frontal sinus, origin, endoscopic surgery, transnasal

\section{Introduction}

Inverted papilloma (IP) is known for local aggressiveness, associated malignancy, high rate of recurrence and tendency to multicentricity ${ }^{(1,2)}$.

The current management of IP involving the nose, ethmoids and or sphenoid sinus is transnasal endoscopic excision ${ }^{(3,4)}$. IP involving the maxillary sinus is managed via transnasal endoscopic medial maxillectomy ${ }^{(3,5)}$ with or without adjuvant sublabial approach ${ }^{(6,7)}$. On the other hand IP involving the frontal sinus (FS) constitutes one of the most challenging issues in the field of sinonasal surgery ${ }^{(8)}$.

The FS is rarely involved in IP, but when it is, the risk of recurrence increases ${ }^{(9,10)}$. The higher recurrence rate for IP involving the FS is likely reflective of greater difficulty in clearing the tumour in the frontal recess (FR) and/or the FS, especially in the setting of previous surgical manipulations ${ }^{(11,12)}$.

Difficulties encountered in transnasal endoscopic surgery of FS IP are related to the upward angled location of the FS. This mandates the need for angled telescopes with difficult orientation, and angled instruments with limited space for manipulation ${ }^{(13)}$. Moreover, the critical location of the FS to nearby important structures is associated with possible complications ${ }^{(8)}$. Surgical strategy usually depends on the location, extension, and size of FS IP, as well as site/s and number of attachment/s within FS (10,12,14-16).

The aim of this article is to emphasise the importance of origin oriented surgery of FS IP. 


\section{Material and methods}

All cases of IP of the sinonasal area operated upon by the first author between February 1996 and October 2011 were retrospectively reviewed to identify cases in which the FS was involved by the tumour. IPs with associated malignancy were excluded. All cases had preoperative CT. The incidence and type of frontal sinus involvement by IP were studied. This was classified into IP originating from the FS itself (Figure 1a, b), IP extending into the FS but originating outside the FS (Figure $2 \mathrm{a}, \mathrm{b})$ and IP with wide origin from inside and outside the FS (Figure $3 a, b)$. The origin and extent of IP as well as associated sinusitis and/or polyps were reviewed. The strategy followed in handling the FS IP concerning the approach followed and the extent of surgery performed was reviewed. Complications and recurrence rate were also studied. Endoscopic follow-up was performed every 3 months and CT and/or MRI were reserved to recurrent cases.

\section{Results}

The FS was involved by IP in 6 out of 119 cases of sinonasal IP (5\%). There were 5 males and one female. Age ranged between 40 and 56 with an average of 49 years. All the 6 cases were recurrent. Number of previous operations ranged between one and three operations.

Concerning tumour location and extension, the nose was involved in $5 / 6$ cases, the nasopharynx in $4 / 6$ cases, the anterior ethmoid in 5/6 cases and the posterior ethmoid in 4/6 cases. Both maxillary and sphenoid sinuses were free of IP in all 6 cases. As regarding tumour location within FS, the medial compartment was involved in all the 6 cases and there was only one case with bilateral extensive lateral compartment involvement.

The origin of the IP was the anterior ethmoid in 2 cases, the FR in 2 cases and the FS proper in one case (medial aspect of posterior wall of the FS). There was one case with wide origin attached to the anterior ethmoid roof, FR and the rim of the frontal ostium (FO). None of these cases originated from the posterior ethmoid, sphenoid, or maxillary sinuses, nasal septum or turbinates. There were 5 cases with unilateral disease, and one case with bilateral disease. There were 2 right-sided lesions and 3 left. All 6 cases showed unifocal attachment at site of origin without any other secondary attachment to mucosa of areas of extension.

Associated sinusitis was noticed in 4 cases and polyps also in 4 cases. Calcification within the tumour mass was encountered in 3 out of 6 cases.

Simple FR clearance (Draf type I) was performed in one case; where the FR was cleared of tumour and the IP inside the FS was delivered easily via the natural FO without any need for
FO widening. Extended frontal sinusotomy (Draf type II) was performed in 4 cases; Draf type lla was done in one case where the FO was widened between the middle turbinate and lamina papyracea. Draf type Ilb was performed in 3 cases, where the FO was widened between the nasal septum and lamina papyracea. One was the case originating from the FS proper and another was the case with wide origin from the anterior ethmoid, FR and FO. Modified Lothrop approach (Draf type III) was applied in one case, where the two FS ostia were widened between the lamina papyracea and nasal septum with removal of the far superior and anterior part of nasal septum and inter frontal sinus septum. Image guided surgery was utilized in 2 cases, one was the case with bilateral extensive calcified lesion and the other was the IP originating from the FS posterior wall. CSF leak was encountered in one case during drilling of tumour origin at the FR. Repair was performed immediately using muco-perichondreum graft from the contra lateral side of nasal septum.

Tumour origin was localized in one case and wide in 5 cases. In all 6 cases, only the mucosa around the origin of IP was sacrificed. Drilling and/or curettage of underneath bone at site of origin were performed in 3 cases. As regarding the case originating from the medial aspect of the posterior wall of the FS, the mucosa around the attachment site was sacrificed and the bone underneath was drilled. Similarly, in the case with wide origin attached to the rim of the FO, the FS mucosa around the FO was sacrificed and the bony edges were curetted. The mucosa and bone distal to the site of origin and attachment site were left undisturbed.

Endoscopic follow up ranged between 12- 42 months with an average of 27 months with no identifiable recurrence at site/s of origin $0 / 6$.

\section{Discussion}

Unfortunately, the data on management of FS IP is sparse, being limited to small patient series precluding meaningful analysis $(10,11,15,17)$. The incidence of FS IP in literature is widely variable. While some surgeons reported a percentage as low as $1.6 \%{ }^{(18)}$, some other studies reported a relatively high incidence of involvement up to $50 \%{ }^{(4)}$. In the current study, FS involvement by IP was noticed in 6 out of 119 cases (5\%).

The general oncologic rules in management of IP are: the tumour should be removed completely, site/s of attachment/s should be precisely and strictly defined, mucosa around the attachment should be sacrificed and the bone at site of attachment should be removed or drilled when needed. Although these tasks are usually achieved easily in IP of the nose, anterior and posterior ethmoids, sphenoid sinus, and medially located maxillary sinus lesions, they are more challenging to perform within the $\mathrm{FS}^{\left({ }^{(8)}\right.}$. 


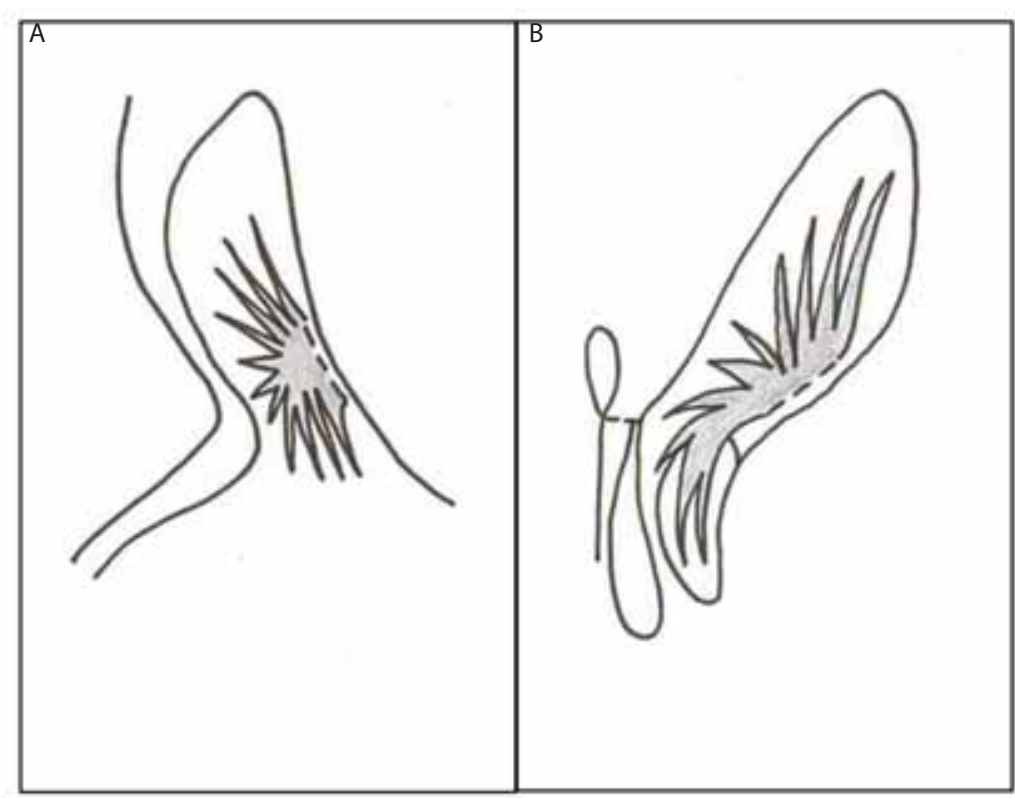

Figure 1. (A) Sagittal and (B) coronal diagrams of inverted papilloma originating from the frontal sinus proper, dotted line indicates tumour origin.
Shohet and Duncavage in 1996 stated that there has not been a single consistently used operation in the literature with proven efficacy to treat FS IP ${ }^{(9)}$. Surgery of FS IP ranges between external osteoplastic flap (OPF) without obliteration (OPF procedure) to transnasal approaches that include; endoscopic simple drainage (FR clearance), endoscopic extended drainage (sinusotomy), and endoscopic median drainage (modified Lothrop) ${ }^{(10)}$. This may be assisted by frontal trephination ${ }^{(19,20)}$.

Factors guiding best options for surgery include size, location, site/s and number of attachment/s and extension of tumour within the FS and whether it is an extension or attachment, experience, and instrumentation $(2,10,12,14-17,21,22)$.

Most of the classifications of IP considered FS involvement as an advanced stage of the disease that necessitates more aggressive surgery. Skolnik et al., ${ }^{(23)}$, classifies FS IP as stage $\mathrm{T} 3$ and he advises frontal sinusectomy with obliteration (one case of FS IP out of 33 IP cases). According to Krouse ${ }^{(4)}$, FS IP is considered stage T3. He suggests either endoscopic or external surgical excision, as needed. Krouse noticed FS involvement in 6 out of 12 IP cases (50\%), which is the highest percentage ever reported in literature. Han et al. ${ }^{(2)}$ classify FS IP as stage 3. They recommended endoscopic modified Lothrop in tumours located in the medial frontal sinus and OPF in case of lateral or superior involvement. On the other hand, Oikawa et al., (22) considered FS IP as stage T3b. They performed lateral rhinotomy in medially located IP (3 FS IP out of 22 IP cases, 13.6\%) and advised OPF in laterally located lesions. According to Cannady et al., (24), FS IP is considered group B but no data was provided on how to handle it. Finally, Dragonetti et al., ${ }^{(16)}$ have rated FS $\mathrm{IP}$ as the most advanced stages (type $\mathrm{V}$, and $\mathrm{VI}$ ). Extension into the medial portion of the sinus no more than halfway into the orbital roof was classified as type V for which Draf II or III was suggested (5 FS IP out of 84 IP cases, $5.9 \%$ ), while extension into the lateral part of the sinus as type VI (2 FS IP out of 84 IP cases, $2.4 \%$ ), and necessitated a combined endoscopic and external approach.

Table 1 shows surgical strategy adopted by different authors in the management of FS IP. It is worthy to notice that initially, external OPF with obliteration was suggested as the treatment of choice ${ }^{(18,23)}$. This was then followed by external OPF without obliteration as the gold standard ${ }^{(9)}$. With the introduction of sinonasal endoscopy, transnasal management was introduced for the management of limited lesions. External OPF was used in advanced tumors to achieve complete excision ${ }^{(2,4)}$. Nowadays, with the accumulation of experience, refinement of FS instruments and image guided surgery (IGS), most cases of FS IP are managed endoscopically transnasally with adjunctive trephination only when needed. OPF is reserved to cases of failure to achieve complete excision ${ }^{(12,16,17,20,26)}$.

Involvement of FS by IP may occur in different settings; primary lesions less frequent than those secondarily invading the FS from the adjacent ethmoid without any mucosal spread. (9,27) Although many authors reported FS involvement by IP, few declared whether it is an extension or attachment and fewer disclosed whether it is an extension or origin of the tumour $(7,12,15)$.

In the current study, FS involvement by IP was an extension of the tumour from the nose into the FS in most of the cases (4/6). The origin of IP was from the anterior ethmoid or frontal recess. None had an origin from the relatively distant posterior ethmoid, sphenoid or maxillary sinus. It was noticed that in these 4 cases, IP was insinuating itself into the FS without 


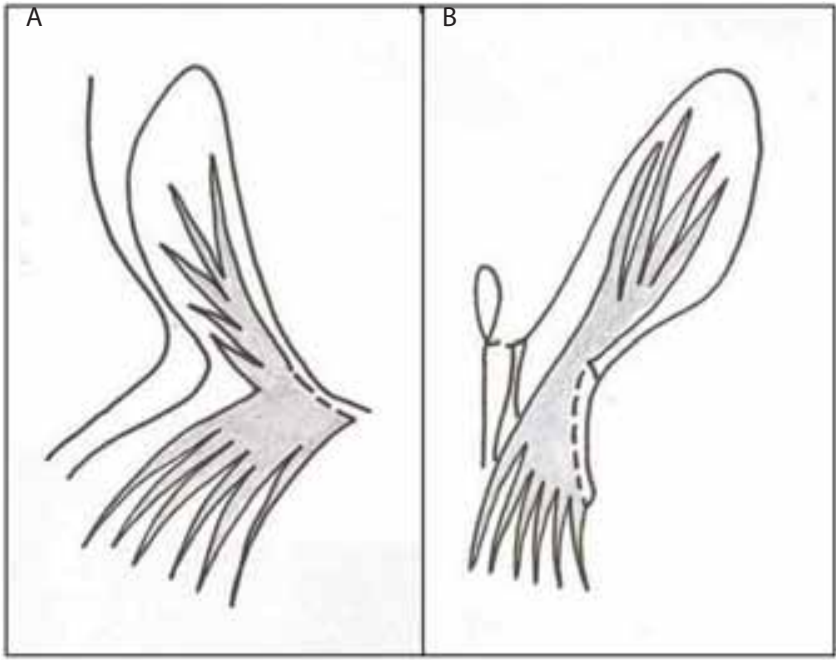

Figure 2. (A) Sagittal and (B) coronal diagrams of inverted papilloma originating from outside frontal sinus and extending into frontal sinus via frontal ostium with no mucosal attachment.

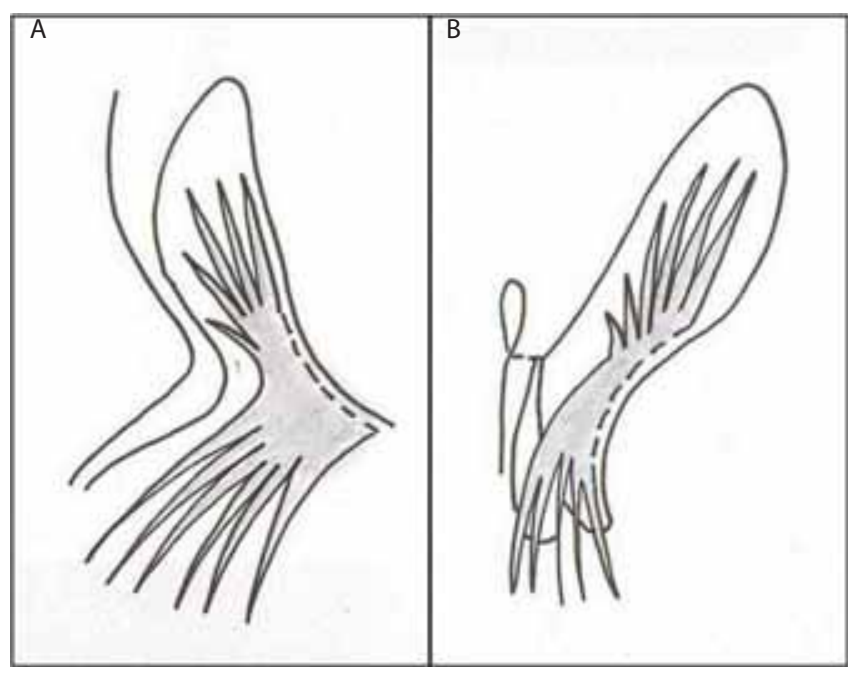

Figure 3. (A) Sagittal and (B) coronal diagrams of inverted papilloma with wide origin from outside and inside the frontal sinus. any secondary attachment to any of the FS walls. In one case, IP had a wide origin attached to the mucosa of the anterior ethmoid, FR and FO (1/6). In another case the tumour was originating from the medial aspect of the posterior wall of the FS proper (1/6).

The authors suggest that surgical strategy of FS IP should change according to whether FS involvement by IP is primary (originating from the FS, either alone or in the form of wide origin from more than one site) or secondary (originating elsewhere and extending to the FS with no mucosal attachment). Moreover, in primary FS IP, the site/s as well as size of origin should be precisely defined. In the current study, all the 6 cases of IP of the FS were taken care of transnasally.

Concerning the case of unilateral IP originating from the medial aspect of the posterior wall of the FS, it was essential to widen the FO and perform Draf type Ilb to achieve good exposure of the origin. Complete excision of the IP was feasible followed by extirpation of a mucosa around site of origin and drilling of the bone underneath.

For the case of IP with wide origin attached to the anterior ethmoid roof, FR and the rim of the FO, it was essential to widen the FO (Draf type Ilb) to remove the tumour and the mucosa around attachment sites in addition to curettage of the bone underneath.

Interestingly, all 4 cases of FS IP extending from outside FS, without any secondary FS mucosal attachment, were associated with FO widening (natural frontal siusotomy). This rendered transnasal endoscopic surgery of FS IP relatively easy and tumour delivery via the natural FO feasible in one case without FO widening (simple FR clearance, Draf type I). Widening of FO was resorted to in 3 cases. Extended frontal sinusotomy was effective in 2 cases; Draf Type lla in one case and type Ilb in the other one. In one case, Draf type III was resorted to where the lesion was bilateral, extensive with medial and far lateral involvement of FS and associated with marked calcification. Although difficulties were encountered, image guidance was of utmost support to deliver the whole lesion transnasally and safely despite calcification and bilateral far lateral location. Definitely, there was no need to insult the FS mucosa and/or touch the bone.

Although some authors suggested that CT and/or MRI might help define site of tumour origin and/or attachment/s (28-30), unfortunately, in most of the cases, the exact site of origin of IP is finalized intra-operatively ${ }^{(15,21,25)}$.

\section{Conclusions}

It is more common for IP to extend into, rather than to originate from the FS. Origin oriented management of FS IP is useful to select the most appropriate approach and optimum extent of surgery.

When IP is originating from outside the FS and insinuating itself into the FS via the FO, it does not acquire any secondary mucosal and/or bony attachments. Accordingly, delivery of the lesion is feasible transnasally endoscopically via the natural FO with or without being widened no matter the extent of the lesion, medial and/or lateral. In such cases, there is no need to touch the FS mucosa and/or insult the bony walls.

If IP originates from the FS proper or with wide origin from outside and inside the FS, removal of the lesion is also feasible transnasally via the natural FO after being widened. Mucosal extirpation around the origin or attachment site/s and drilling 


\begin{tabular}{|c|c|c|c|c|c|c|c|}
\hline Author/s & Year & $\begin{array}{l}\text { Cases } \\
(\%)\end{array}$ & Surgical strategy & $\begin{array}{l}\text { Surgery performed and/or recom- } \\
\text { mended }\end{array}$ & Surgical approach & $\begin{array}{l}\text { Mean } \\
\text { follow up } \\
\text { (years) }\end{array}$ & R3ecurrence \\
\hline Skolnik et al. ${ }^{23}$ & 1966 & $\begin{array}{l}1 / 33 \\
(3 \%)\end{array}$ & $\begin{array}{l}\text { External approach } \\
\text { in all cases }\end{array}$ & $\begin{array}{l}\text { Frontal sinusectomy + obliteration } \\
\text { (one case) }\end{array}$ & OPF + obliteration & - & - \\
\hline $\begin{array}{l}\text { Bielamowicz } \\
\text { et al. }{ }^{18}\end{array}$ & 1993 & $\begin{array}{c}1 / 61 \\
(1.6 \%)\end{array}$ & $\begin{array}{l}\text { External approach } \\
\text { in all cases }\end{array}$ & Obliteration of the FS (one case) & OPF + obliteration & - & - \\
\hline $\begin{array}{l}\text { Shohet and } \\
\text { Duncavage }^{9}\end{array}$ & 1996 & 2 & $\begin{array}{l}\text { External approach } \\
\text { in all cases }\end{array}$ & $\begin{array}{l}\text { OPF frontal sinusectomy without } \\
\text { obliteration ( } 2 \text { cases) }\end{array}$ & $\begin{array}{l}\text { OPF without oblit- } \\
\text { eration }\end{array}$ & 1.5 & 0 \\
\hline Krouse $^{4}$ & 2001 & $\begin{array}{l}6 / 12 \\
(50 \%)\end{array}$ & $\begin{array}{l}\text { According to } \\
\text { the stage of the } \\
\text { disease (limited or } \\
\text { advanced) }\end{array}$ & $\begin{array}{l}\text { Endoscopic: if seems adequate (? Cases) } \\
\text { External: if there is any doubt of com- } \\
\text { plete removal (? cases) }\end{array}$ & $\begin{array}{l}\text { Endoscopic or OPF } \\
\text { without oblitera- } \\
\text { tion }\end{array}$ & 3.3 & 1 (16.7\%) \\
\hline Han et al. ${ }^{2}$ & 2001 & $\begin{array}{c}7 / 31 \\
(16.2 \%)\end{array}$ & $\begin{array}{l}\text { According to } \\
\text { the stage of the } \\
\text { disease (limited or } \\
\text { advanced) }\end{array}$ & $\begin{array}{l}\text { Endoscopic modified Lothrop ( } 2 \text { cases) } \\
\text { in IP located in the medial FS } \\
\text { Endoscopic + adjuvant OPF without } \\
\text { obliteration ( } 4 \text { cases) when lateral or } \\
\text { superior FS is involved } \\
\text { External: Sublabial, medial maxillec- } \\
\text { tomy and OPF ( } 1 \text { case) }\end{array}$ & $\begin{array}{l}\text { Endoscopic or } \\
\text { OPF without oblit- } \\
\text { eration }\end{array}$ & 4.17 & $1(14.3 \%)$ \\
\hline $\begin{array}{l}\text { Loehrl and } \\
\text { Smith }\end{array}$ & 2004 & 2 & $\begin{array}{l}\text { According to ex- } \\
\text { tent and location }\end{array}$ & $\begin{array}{l}\text { Endoscopic extended frontal sinu- } \\
\text { sotomy ( } 1 \text { case) in unilateral IP located } \\
\text { inferiorly } \\
\text { Modified Lothrop ( } 0 \text { cases) in uni- or } \\
\text { bilateral IP located posteriorly and } \\
\text { medially } \\
\text { External: OPF without obliteration } \\
\text { (1 case) in uni- or bilateral IP located } \\
\text { anteriorly and laterally }\end{array}$ & $\begin{array}{l}\text { Endoscopic or } \\
\text { OPF without oblit- } \\
\text { eration }\end{array}$ & 3.5 & 0 \\
\hline Batra et al..$^{20}$ & 2005 & 2 & $\begin{array}{l}\text { Combined endo- } \\
\text { scopic }+ \text { trephina- } \\
\text { tion in all cases }\end{array}$ & $\begin{array}{l}\text { Endoscopic frontal sinusotomy + } \\
\text { endoscopic trephination ( } 2 \text { cases) }\end{array}$ & $\begin{array}{l}\text { Endoscopic + } \\
\text { trephination }\end{array}$ & 1.4 & 0 \\
\hline $\begin{array}{l}\text { Bushwald and } \\
\text { Larsen }^{6}\end{array}$ & 2005 & $\begin{array}{l}13 / 42 \\
(31 \%)\end{array}$ & $\begin{array}{l}\text { Endoscopic ap- } \\
\text { proach in all cases }\end{array}$ & Endoscopic (13 cases) & Endoscopic & 3 & $3(23 \%)$ \\
\hline Dubin et al. ${ }^{11}$ & 2005 & $\begin{array}{c}6 / 18 \\
(33.3 \%)\end{array}$ & $\begin{array}{l}\text { According to size } \\
\text { and location }\end{array}$ & $\begin{array}{l}\text { OPF + endoscopic frontal sinusotomy } \\
\text { (1 case), in IP located laterally in a well } \\
\text { pneumatized FS } \\
\text { Endoscopic frontal sinusotomy ( } 2 \\
\text { cases) } \\
\text { Staged endoscopic followed by OPF } \\
\text { (3 cases), when endoscopy failed to } \\
\text { achieve adequate excision }\end{array}$ & $\begin{array}{l}\text { Endoscopic } \pm \text { OPF } \\
\text { without oblitera- } \\
\text { tion or Staged En- } \\
\text { doscopic followed } \\
\text { by OPF }\end{array}$ & 1.1 & $3(50 \%)$ \\
\hline Kamel et al. ${ }^{25}$ & 2005 & $\begin{array}{l}0 / 70 \\
(0 \%)\end{array}$ & $\begin{array}{l}\text { According to } \\
\text { extension }\end{array}$ & $\begin{array}{l}\text { Transnasal endoscopic delivery } \\
\text { through the FO } \\
\text { External approach in case of failure to } \\
\text { achieve complete excision from the far } \\
\text { lateral FS compartment }\end{array}$ & $\begin{array}{l}\text { Endoscopic or OPF } \\
\text { without oblitera- } \\
\text { tion }\end{array}$ & 6.5 & 0 \\
\hline Nicolai et al. ${ }^{21}$ & 2006 & $-/ 98(-)$ & $\begin{array}{l}\text { According to } \\
\text { degree of FS } \\
\text { involvement }\end{array}$ & $\begin{array}{l}\text { Endoscopic frontal sinusotomy (Draf } \\
\text { Ila) as a routine in IP not involving the FS } \\
\text { and in small digitation protruding into } \\
\text { the frontal lumen not spreading along } \\
\text { the mucosa } \\
\text { Endoscopic frontal sinusotomy (Daf } \\
\text { Ilb or III) in FS IP with a major involve- } \\
\text { ment } \\
\text { Combined OPF and transnasal ap- } \\
\text { proaches in IP involving the anterior } \\
\text { wall or lateral part of an extensively } \\
\text { pneumatized FS }\end{array}$ & $\begin{array}{l}\text { Endoscopic } \pm \text { OPF } \\
\text { without oblitera- } \\
\text { tion }\end{array}$ & - & - \\
\hline $\begin{array}{l}\text { Draf and } \\
\text { Minovi }{ }^{14}\end{array}$ & 2006 & 0 & $\begin{array}{l}\text { According to } \\
\text { extension }\end{array}$ & $\begin{array}{l}\text { Endoscopic Draf III (modified Lothrop) } \\
\pm \text { external approach: in IP medial } \\
\text { to a vertical line through the lamina } \\
\text { papyracea } \\
\text { External approach: in FS IP lateral to } \\
\text { this line }\end{array}$ & $\begin{array}{l}\text { Endoscopic or } \\
\text { external approach }\end{array}$ & 0 & 0 \\
\hline
\end{tabular}




\begin{tabular}{|c|c|c|c|c|c|c|c|}
\hline Author/s & Year & $\begin{array}{l}\text { Cases } \\
(\%)\end{array}$ & Surgical strategy & $\begin{array}{l}\text { Surgery performed and/or recom- } \\
\text { mended }\end{array}$ & Surgical approach & $\begin{array}{l}\text { Mean } \\
\text { follow up } \\
\text { (years) }\end{array}$ & R3ecurrence \\
\hline Sautter et al. ${ }^{17}$ & 2007 & 5 & $\begin{array}{l}\text { According to the } \\
\text { extent }\end{array}$ & $\begin{array}{l}\text { Computer-aided endoscopic resection } \\
\text { (4 cases) } \\
\text { + endoscopic frontal trephination } \\
\text { (1 case) }\end{array}$ & $\begin{array}{l}\text { Endoscopic } \pm \\
\text { trephination }\end{array}$ & 1.4 & 0 \\
\hline Oikawa et al. ${ }^{22}$ & 2007 & $\begin{array}{c}3 / 22 \\
(13.6 \%)\end{array}$ & $\begin{array}{l}\text { External approach } \\
\text { in all cases }\end{array}$ & $\begin{array}{l}\text { External approach: Lateral rhinotomy, } \\
\text { and medial maxillectomy ( } 3 \text { cases) } \\
\text { OPF: for laterally extending IP ( } 0 \text { cases) }\end{array}$ & External approach & 1.8 & 0 \\
\hline $\begin{array}{l}\text { Lawson and } \\
\text { Patel }^{7}\end{array}$ & 2009 & $\begin{array}{l}14 / 200 \\
(7 \%)\end{array}$ & $\begin{array}{l}\text { According to the } \\
\text { location }\end{array}$ & $\begin{array}{l}\text { Lateral rhinotomy in nasofrontal } \\
\text { tumors ( } 12 \text { cases) } \\
\text { OPF in IP of the FS proper ( } 2 \text { case) } \\
\pm \text { Endoscopic frontal sinusotomy }\end{array}$ & $\begin{array}{l}\text { Lateral rhinotomy, } \\
\text { or OPF, } \pm \text { endo- } \\
\text { scopic }\end{array}$ & 4.3 & - \\
\hline $\begin{array}{l}\text { Bit-Na Yoon et } \\
\text { al. }^{12}\end{array}$ & 2009 & 18 & $\begin{array}{l}\text { According to the } \\
\text { site and number } \\
\text { of attachments }\end{array}$ & $\begin{array}{l}\text { OPF without obliteration ( } 2 \text { cases, early } \\
\text { in their study, can be avoided in most } \\
\text { cases) } \\
\text { Endoscopic frontal sinusotomy: in uni- } \\
\text { focal FS IP attached to medial/posterior } \\
\text { walls ( } 7 \text { cases) + adjuvant endoscopic } \\
\text { frontal trephination: in multifocal FS IP } \\
\text { ( } 3 \text { cases) } \\
\text { Endoscopic modified Lothrop in multi- } \\
\text { focal FS IP ( } 4 \text { cases) + adjuvant endo- } \\
\text { scopic frontal trephination: in multifocal } \\
\text { FS IP, specially with attachment to the } \\
\text { anterior, lateral walls or contralateral FS } \\
\text { ( } 2 \text { cases) }\end{array}$ & $\begin{array}{l}\text { Endoscopic } \pm \\
\text { trephination }\end{array}$ & 3.5 & $4(22 \%)$ \\
\hline Eweiss et al. ${ }^{15}$ & 2009 & $\begin{array}{c}4 / 34 \\
(11.8 \%)\end{array}$ & $\begin{array}{l}\text { According to } \\
\text { origin and degree } \\
\text { of involvement of } \\
\text { the FS mucosa }\end{array}$ & $\begin{array}{l}\text { Endoscopic endonasal resection: in } \\
\text { FS IP expanding from the frontal recess } \\
\text { ( } 3 \text { cases) } \\
\text { Endoscopic + osteoplastic flap: in FS IP } \\
\text { originating from within the frontal sinus } \\
\text { with massive involvement of the sinus } \\
\text { mucosa ( } 1 \text { case) }\end{array}$ & $\begin{array}{l}\text { Endoscopic } \\
\pm \text { OPF }\end{array}$ & 1.3 & $1(25 \%)$ \\
\hline $\begin{array}{l}\text { Dragonetti et } \\
\text { al. }^{16}\end{array}$ & 2011 & $\begin{array}{l}7 / 84 \\
(8.3 \%)\end{array}$ & $\begin{array}{l}\text { According to } \\
\text { location and } \\
\text { extension }\end{array}$ & $\begin{array}{l}\text { Ethmoid centripetal resection + } \\
\text { frontal osteoplasty DRAF II- III: in FS } \\
\text { IP extending into the medial portion of } \\
\text { the sinus no more than halfway into the } \\
\text { orbital roof; type V ( } 5 \text { cases) } \\
\text { Combined endoscopic and external } \\
\text { approach: in FSIP extending into the } \\
\text { lateral portion of the sinus; type VI ( } 2 \\
\text { cases) }\end{array}$ & $\begin{array}{l}\text { Type V endoscopic, } \\
\text { Type VI combined } \\
\text { approach }\end{array}$ & 3.25 & $1(20 \%)$ \\
\hline $\begin{array}{l}\text { Kamel et al. } \\
\text { (current study) }\end{array}$ & 2011 & $\begin{array}{l}6 / 115 \\
(5.2 \%)\end{array}$ & $\begin{array}{l}\text { According to } \\
\text { origin solely }\end{array}$ & $\begin{array}{l}\text { Transnasal } \pm \text { FO widening; no insult to } \\
\text { FS mucosa or bone: in FS IP originating } \\
\text { outside FS with no FS mucosal attach- } \\
\text { ment ( } 4 \text { cases, FO widening in } 3 \text { cases) } \\
\text { Tranasnasal + FO widening + removal } \\
\text { of surrounding mucosa + removal } \\
\text { or drilling of underlying bone: in IP } \\
\text { originating from FS proper ( } 1 \text { case), and } \\
\text { IP with wide origin from more than one } \\
\text { site including the FS ( } 1 \text { case) } \\
\pm \text { Adjuvant frontal trephination or OPF } \\
\text { without obliteration in case of failure to } \\
\text { achieve complete excision ( } 0 \text { cases) }\end{array}$ & $\begin{array}{l}\text { Endoscopic frontal } \\
\text { sinusotomy (Draf I, } \\
\text { II or III), } \\
\pm \text { Trephination } \\
\text { or OPF without } \\
\text { obliteration }\end{array}$ & 1.18 & 0 \\
\hline
\end{tabular}

"Mean follow up (years)" column represents the average follow up period for the total number of cases included in the study, not only those involving the frontal sinus The number of recurrent cases number presented is specific for cases involving the frontal sinus.

OPF: osteoplastic flap, FS: frontal sinus, FO: frontal ostium, IP: inverted papilloma, - : data is unavailable. 
or curettage of the bone underneath are mandatory.

In case of failure to achieve complete exposure and/or excision of FS IP, adjunct trephination or OPF may be resorted to. This is a preliminary report of only 6 cases of FS IP that mandates long term follow-up.

\section{Authorship contribution}

RHK: Performing all surgeries, writing and revising the manuscript; AFAF: Data collection and analysis, assistance in writing and revising the manuscript; AGA: Gathering data, and preparing table, assistance in writing and revising the manuscript.

\section{Conflict of interest}

None.

\section{References}

1. Lawson W, Kaufman MR, Biller HF. Treatment outcomes in the management of inverted papilloma: an analysis of 160 cases. Laryngoscope 2003; 113: 1548-1556.

2. Han JK, Smith TL, Loehrl T, Toohill RJ, Smith MM. An evolution in the management of sinonasal inverting papilloma. Laryngoscope 2001; 111: 1395-1400.

3. Kamel RH. Transnasal endoscopic medial maxillectomy in inverted papilloma. Laryngoscope 1995; 105: 847-853.

4. Krouse $\mathrm{JH}$. Endoscopic treatment of inverted papilloma: safety and efficacy. Am J Otolaryngol 2001; 22: 87-99.

5. Sukenik MA, Casiano R. Endoscopic medial maxillectomy for inverted papillomas of the paranasal sinuses: value of the intraoperative endoscopic examination. Laryngoscope 2000; 110: 39-42

6. Buchwald CV, Larsen AS. Endoscopic surgery of inverted papilloma under image guidance-A prospective study of 42 consecutive cases at a Danish university clinic. Otolaryngol Head Neck Surg 2005; 132: 602-607.

7. Lawson W, Patel Z.M. The evolution of management for inverted papilloma: An analysis of 200 cases. Otolaryngol Head Neck Surg 2009; 140: 330-335

8. Melroy CT, Dubin MG, Senior B.A. Management of benign frontal sinus tumors with osteoplastic flap without obliteration. Oper Tech Otolaryngol Head Neck Surg 2004; 15: 16-22

9. Shohet JA, Duncavage JA. Management of frontal sinus with inverted papilloma. Otolaryngol Head Neck Surg 1996; 114 649-652.

10. Loehrl TA, Smith TL. Options in the management of inverting papilloma involving the frontal sinus. Oper Tech Otolaryngol Head Neck Surg 2004; 15: 32-36.

11. Dubin MG, Sonnenburg RE, Melroy CT, Ebert CS, Coffey CS, Senior BA. Staged endoscopic and combined open/endoscopic approach in the management of inverted papilloma of the frontal sinus. Am J Rhinol 2005; 19 : 442-445.

12. Yoon BN, Batra PS, Citardi MJ, Roh HJ. Frontal sinus inverted papilloma. Surgical strategy based on the site of attachment. Am J Rhinol Allergy 2009; 23: 337-341.

13. Becker SS, Bomeli SR, Gross CW, Han JK. Limits of endoscopic visualization and instrumentation in the frontal sinus. Otolaryngol Head Neck Surg 2006; 135:
917-921.

14. Draf W, Minovi A. The "Frontal $T$ " in the refinement of endonasal frontal sinus type III drainage. Oper Tech Otolaryngol 2006: 17: 121-125.

15. Eweiss A, Al Ansari A, Hassab M. Inverted papilloma involving the frontal sinus: a management plan. Eur Arch Otorhinolaryngol. 2009; 266: 1895-1901.

16. Dragonetti A, Gera R, Sciuto A, Scotti A, Bigoni A, Barbaro E, Minni A. Sinonasal inverted papilloma: 84 patients treated by endoscopy and proposal for a new classification. Rhinology 2011; 49: 207-213.

17. Sautter NB, Citardi MJ, Batra PS. Minimally invasive resection of frontal recess/sinus inverted papilloma. Am J Rhinol-Head Neck Med Surg 2007; 28: 221-224.

18. Bielamowicz S, Calcaterra TC, Watson D. Inverting papilloma of the head and the neck: UCLA update. Otolaryngol Head Neck Surg 1993; 109: 71-76.

19. Han JK, Hwang PH. Image-guided trephination of the frontal sinus: An adjunct to endoscopic technique. Oper Tech Otolaryngol Head Neck Surg 2004; 15: 57-60.

20. Batra PS, Citardi MJ, Lanza DC. Combined endoscopic trephination and endoscopic frontal sinusotomy for management of complex frontal sinus pathology. Am J Rhinol 2005; 19: 435-441.

21. Nicoli P, Tomenzoli D, Lombardi D, Maroldi R. Different endoscopic options in the treatment of inverted papilloma. Oper Tech Otolaryngol 2006; 17: 80-86.

22. Oikawa K, Furuta Y, Nakamaru Y, Oridate N, Fukuda S. Preoperative staging and surgical approaches for sinonasal inverted papilloma. Ann Otol Rhinol Laryngol 2007; 116 : 674-680.

23. Skolnick EM, Loewy A, and Friedman JE. Inverted papilloma of the nasal cavity. Arch Otolaryngol 1966; 64: 83-89.

24. Cannady SB, Batra PS, Sautter NB, Roh H.J, Citardi M.J. New staging system for sinonasal inverted papilloma in the endoscopic era. Laryngoscope 2007; 117: 1283-1287.

25. Kamel R, Khaled A, Kandil T. Inverted papilloma: new classification and guidelines for endoscopic surgery. Am J Rhinol 2005; 19: 358-364.

26. Philpott CM, Dharamsi A, Witheford M, Javer AR. Endoscopic management of inverted papillomas: long-term results, the St. Pauls Sinus Centre experience. Rhinology 2010; 48: 358-363.

27. Vrabec DP. The inverted schneiderian papil- loma: a 25-year study. Laryngoscope 1994; 104: 582-605.

28. Yousuf K, Wright ED. Site of attachment of inverted papilloma predicted by CT findings of osteitis. Am J Rhinol 2007; 21: 32-36.

29. Sham CL, King AD, van Hasselt A, Tong MC. The roles and limitations of computed tomography in the preoperative assessment of sinonasal inverted papillomas. Am J Rhinol 2008; 22: 144-150.

30. limura J, Otori N, Ojiri H, Moriyama H. Preoperative magnetic resonance imaging for localization of the origin of maxillary sinus inverted papillomas. Aurus Nasus Larynx 2009; 36: 416-421.

\section{Reda Kamel}

Professor of Rhinology

Cairo University

61 Canal Street

Maadi - Cairo - 11431

Egypt

Mobile: 002-0122-2137172

E-mail: rhinology@redakamel.com rkamel55@hotmail.com

Web site: www.redakamel.com 